\title{
Combined PGT for Breast Cancer and Other Inherited Conditions
}

\author{
Svetlana Rechitsky ${ }^{1}$, Tatiana Pakhalchuk ${ }^{1}$, Maria Prokhorovich ${ }^{1}$, Anver Kuliev ${ }^{1}$ \\ ${ }^{1}$ Reproductive Genetic Innovations, 2910 MacArthur Blvd, Chicago, IL 60062
}

Corresponding Author: Anver Kuliev, Reproductive Genetic Innovations, 2910 MacArthur Blvd, Chicago, IL 60062

Received date: December 04, 2021; Accepted date: December 17, 2021; Published date: January 07, 2022

Citation: Rechitsky S., Pakhalchuk T., Prokhorovich M., Kuliev A. (2022) Combined PGT for Breast Cancer and Other Inherited Conditions. J. Obstetrics Gynecology and Reproductive Sciences; 6(2) DOI:10.31579/2578-8965/112

Copyright: (c) 2022, Anver Kuliev, This is an open access article distributed under the Creative Commons Attribution License, which permits unrestricted use, distribution, and reproduction in any medium, provided the original work is properly cited.

\begin{abstract}
Inherited cancer predisposition is presently one of the major indications for preimplantation genetic testing (PGT), providing an option for couplers at risk to avoid the birth of an offspring with predisposition to cancer. We present here our experience of 35 of 874 PGT cycles for cancer, in which in addition to BRCA1/2 the couples were at risk to another genetic conditions as well, for which PGT was performed together with PGT for breast cancer. This resulted in birth of 20 mutation free children with not only unaffected for the tested genetic condition, but also without risk of developing cancer. This is a part of our overall PGT series of 6,204 PGT cases for monogenic disorders (PGT-M), with 2,517 resulting births, free of genetic disorder. The accumulated experience, demonstrates considerable progress in using PGT for avoiding the birth of affected children together with avoiding predisposition to cancer.

Key Words: preimplantation genetic testing (PGT)/ PGT for monogenic disorders (PGT-M)/ breast cancer/ BRCA 1/ BRCA2/ PGT for BRCA 1/2 concomitant with other conditions
\end{abstract}

\section{Introduction}

Preimplantation genetic testing (PGT) was shown to be an attractive option for couples at risk, allowing to avoid the inheritance of cancer predisposing genes to their offspring [1-6]. As there is no sufficient progress in developing effective approaches to prevent the development of cancer in carries of cancer predisposing mutations, the number of referrals for PGT of cancer has increased significantly during the last few years, especially after introduction of an expanding carrier screening, which also picks up genetic risk for having an affected child caused by additional monogenic disorders. The most frequent cancer for which such combined PGT-M was performed were BRCA1 and BRCA2, currently representing one of the most frequent PGT-M indications [7].

Thus, this paper will describe our experience of PGT for breast cancer predisposition, which was performed together with testing for additional single gene disorders, resulting in avoiding the birth of affected child with monogenic disorder, as well as without BRCA genes predisposing to developing breast cancer.

\section{Material and Methods}

A series of 36 PGT cycles for 19 couples at risk for producing a progeny with BRCA $1 / 2$ mutations predisposing to breast cancer and at risk for additional single gene disorders was performed (list of gene mutations, for which PGT was performed together with BRCA $1 / 2$ is presented in Table 1).
PGT cycles were performed using a standard IVF protocol, coupled with micromanipulation procedures of polar bodies (PB) or embryo biopsy, described in detail elsewhere [8]. Details of PGT guidelines were reported previously [9-10]. The present standards of the procedure involve whole genome amplification (WGA) of biopsied PBs or embryos biopsy samples, followed by multiplex nested PCR analysis of the mutations in question, together with closely linked genetic markers in a multiplex heminested system. The majority of cases are currently performed by blastocyst biopsy followed by WGA [8]. The biopsied blastocyst samples were tested by the multiplex nested PCR analysis, involving the mutations in question and linked marker analysis in a multiplex heminested system (in each family, heterozygous alleles and haplotypes not shared by parents were selected). This allowed detecting and avoiding misdiagnosis due to preferential amplification and allele dropout (ADO), and a possible aneuploidy or uniparental disomy of chromosomes in which the tested mutations are located, which may affect diagnostic accuracy of PGT. In PGT cycles, involving an advanced reproductive age of maternal partner, aneuploidy testing was also performed by next generation technologies (NGS) (Illumina Inc) for 24-chromosome aneuploidy testing [7, 11].

\section{Results and Discussion}

Table 1 presents the results of PGT-M series of 36 PGT cycles performed for BRCA1/2 concomitant with other genetic conditions: 24 cycles involved testing for BRCA1 and 12 for BRCA2, resulting in birth of 15 healthy children unaffected for the additional one or two conditions, also free from predisposition genes to breast cancer (10 free of BRCA1 and 5 
free of BRCA2 mutations). Increasing number of such a combined PGT$\mathrm{M}$ is not surprising, as breast cancer has become one of the commonest indications for PGT-M. Figure 1 shows a steady increase of the numbers of PGT-M for breast cancer since we performed the first PGT case in 1999 [3]. The number of cases is increasing annually, reaching close to 200 cases in the current year. The presented results in Table 1 is a part of our overall PGT series of 6,204 PGT cases for monogenic disorders, which resulted in 2,517 births free of genetic disorder. Overall, this included 874 PGT cycles for cancer, of which 284 PGT were performed for breast cancer caused by BRCA1 and BRCA2 mutation, resulting in identification and transfer of 280 embryos free from mutations predisposing to breast cancer in 199 cycles, yielding 131 pregnancies and birth of 134 children without risk of developing breast cancer due to BRCA1 and BRCA2 genes [7].

\begin{tabular}{|c|c|c|c|c|c|c|c|}
\hline CONDITIONS & Gene & $\begin{array}{l}\text { H } \\
\text { Pati } \\
\text { ont }\end{array}$ & $\begin{array}{l}\text { H } \\
\text { Cycl } \\
0\end{array}$ & \# Transfers & $\begin{array}{l}\text { Embryo } \\
\text { transfer } \\
\text { red }\end{array}$ & $\begin{array}{l}\text { Pregua } \\
\text { ncy }\end{array}$ & $\begin{array}{l}\text { Birt } \\
\text { h }\end{array}$ \\
\hline $\begin{array}{l}\text { BREAST-OVARIAN CANCER, FAMILIAL, } \\
\text { SUSCEPTIBILITY TO, 1: BREAST- } \\
\text { OVARIAN CANCER, } \\
\text { SUSCEPTIBILITY TO, } 2\end{array}$ & $\begin{array}{l}B R C A 1 \\
B R C A 2\end{array}$ & 7 & 13 & 10 & 10 & 6 & 5 \\
\hline $\begin{array}{l}\text { BREAST-OVARIAN CANCER, FAMILIAL, } \\
\text { SUSCEPTIBILITY TO, 1; BIOTINIDASE } \\
\text { DEFICIENCY }\end{array}$ & $\begin{array}{l}B R C A 1 \\
B T D\end{array}$ & 1 & 1 & 0 & 0 & 0 & 0 \\
\hline $\begin{array}{l}\text { BREAST-OVARIAN CANCER, FAMILIAL, } \\
\text { SUSCEPTIBILITY TO, } \mathbf{1} \\
\text { DYSTONIA } 1 \text {, TORSION, AUTOSOMAL } \\
\text { DOMINANT }\end{array}$ & $\begin{array}{l}\text { BRCAI } \\
\text { TORIA }\end{array}$ & 1 & 1 & 1 & 1 & 1 & 1 \\
\hline $\begin{array}{l}\text { BREAST-OVARIAN CANCER, FAMILLAL, } \\
\text { SUSCEPTIBILITY TO, 1; } \\
\text { FRAGILE X MENTAL RETARDATION } \\
\text { SYNDROME }\end{array}$ & $\begin{array}{l}\text { BRCAI } \\
\text { FMRI }\end{array}$ & 1 & 2 & 1 & 1 & 1 & 1 \\
\hline $\begin{array}{l}\text { BREAST-OVARIAN CANCER, FAMILIAL, } \\
\text { SUSCEPTIBILITY TO, 1; } \\
\text { MUCOPOLYSACCHARIDOSIS, TYPE IIIA }\end{array}$ & $\begin{array}{l}\text { BRCAl } \\
\text { SGSH }\end{array}$ & 1 & 2 & 1 & 1 & 0 & 0 \\
\hline $\begin{array}{l}\text { BREAST-OVARIAN CANCER, FAMILIAL, } \\
\text { SUSCEPTIBILITY TO, } 1 \text {; } \\
\text { SPINAL MUSCULAR ATROPHY, TYPE I }\end{array}$ & $\begin{array}{l}\text { BRCAI } \\
\text { SMN1 }\end{array}$ & 1 & 1 & 1 & 2 & 1 & 2 \\
\hline $\begin{array}{l}\text { BREAST-OVARIAN CANCER, FAMILIAL, } \\
\text { SUSCEPTIBILITY } \\
\text { ARTHROGRYPOSIS, } \\
\text { DYSFUNCTION, AND CHOLESTASIS } 1\end{array}$ & $\begin{array}{l}\text { BRCAI } \\
\text { VPS33B }\end{array}$ & 1 & 4 & 3 & 4 & 2 & 1 \\
\hline BRCA1+SECOND CONDITION & $\begin{array}{l}\text { SUBT } \\
\text { OTAL }\end{array}$ & 13 & 24 & 17 & 19 & 11 & 10 \\
\hline $\begin{array}{l}\text { BREAST-OVARIAN CANCER, FAMILIAL, } \\
\text { SUSCEPTIBILITY TO } 2 \text {; } \\
\text { BREAST AND COLORECTAL CANCER, } \\
\text { SUSCEPTIBILITY }\end{array}$ & $\begin{array}{l}\text { BRCA2 } \\
\text { CHER2 }\end{array}$ & 1 & 3 & 2 & 2 & 1 & 1 \\
\hline $\begin{array}{l}\text { BREAST-OVARIAN CANCER, FAMILIAL, } \\
\text { SUSCEPTIBILITY TO 2; } \\
\text { TAY-SACHS DISEASE }\end{array}$ & $\begin{array}{r}B R C A 2 \\
\text { HEXA }\end{array}$ & 1 & 1 & 1 & 0 & 0 & 0 \\
\hline $\begin{array}{l}\text { BREAST-OVARIAN CANCER, FAMILIAL, } \\
\text { SUSCEPTIBILITY TO } 2 \text { 2; MULTIPLE } \\
\text { ENDOCRINE NEOPLASIA, TYPE I }\end{array}$ & $\begin{array}{l}B R C A 2 \\
M E N 1\end{array}$ & 2 & 6 & 3 & 5 & 2 & 3 \\
\hline $\begin{array}{l}\text { BREAST-OVARLAN CANCER, FAMILLAL, } \\
\text { SUSCEPTIBILITY TO } 2 \\
\text { ALZHEIMER DISEASE } 4\end{array}$ & $\begin{array}{l}\text { BRCA2 } \\
\text { PSEN2 }\end{array}$ & 1 & 1 & 1 & 2 & 1 & 1 \\
\hline $\begin{array}{l}\text { BREAST-OVARIAN CANCER, FAMILIAL, } \\
\text { SUSCEPTIBILITY TO } 2 \text {; } \\
\text { TRANSLOCATION }\end{array}$ & $\begin{array}{l}\text { BRCA2 } \\
\text { TL }\end{array}$ & 1 & 1 & 1 & $\mathbf{0}$ & 0 & 0 \\
\hline$B R C A 2+S E C O N D$ CONDITION & $\begin{array}{l}\text { SUBT } \\
\text { OTAL }\end{array}$ & 6 & 12 & 8 & 9 & 4 & 5 \\
\hline $\begin{array}{l}\text { ALL BREST CANCER TYPE+ SECOND } \\
\text { CONDITION }\end{array}$ & TOTAL & 19 & 36 & 25 & 28 & 15 & 15 \\
\hline
\end{tabular}


Of special interest were PGT for BRCA 1/2 combined with PGT for two additional conditions, each resulting in birth of unaffected child for both conditions, as well as free from predisposition to breast cancer. Another case of special interest was PGT-M in a couple with paternal partner carrying BRCA2 and maternal partner carrying BRCA1 mutations. Of 6 tested blastocysts tested, 2 were carriers of BRCA1, 1 carrier of BRCA2,
2 were free from BRCA1 and BRCA2 mutations but had chromosomal aneuploidy, and only one was euploid and also a non-carrier of BRCA1 and BRCA 2 mutations, which was transferred, resulting in a breast cancer predisposition free child.

Figure Legends

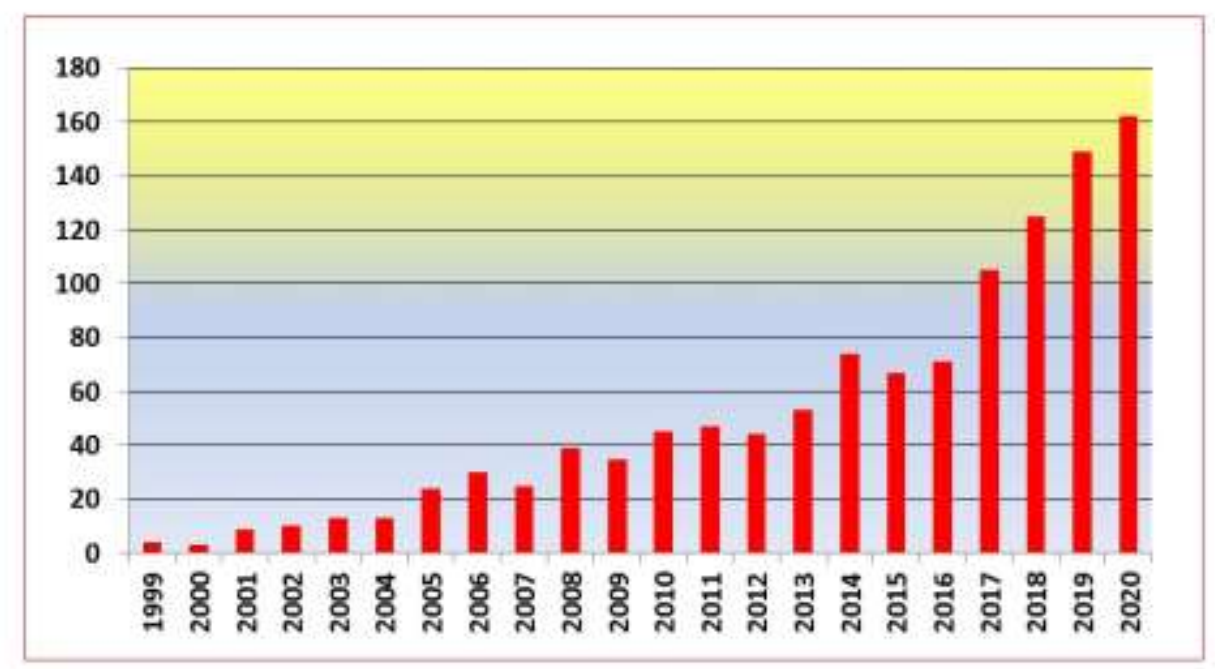

Figure 1 Steady Increase of PGT-M cycles for cancer predisposition, since the first case performed in 1999 [3], up to 200 cases in the current year (not shown)

Upper Panel shows the family pedigree with paternal mutation BRCA1 gene, 3100 del GT presented on the left, and maternal fragile X expansion on the right. As seen from pedigree, the paternal partner inherited the breast cancer predisposing gene from his mother. As chances to produce an embryos free of each of these gene is $50 \%$, only 1 in four embryos could be expected to be free of both genes to be detected in PGT-M. The couple have already affected boy with FMR1 gene.

Meddle Panel shows the results of testing of 10 embryos following trophectoderm biopsy, of which only 3 were free of the paternal BRCA1 gene (embryo \#3, 7 and 9).
Lower Panel shows the result of testing these 10 embryos for FMR gene, 7 of which were without fragile X expansion FMR1 gene, including 2 of 3 embryos free of BRCA 1 gene (embryo \#3 and 7). So 2 of 10 embryos were free of both mutations, which is close to the above expected chances of getting unaffected embryo for transfer.

One of these embryos (embryo \#3) was transferred, resulting in unaffected pregnancy and birth of baby girl free of FMR gene expansion and with no predisposition to breast cancer. 


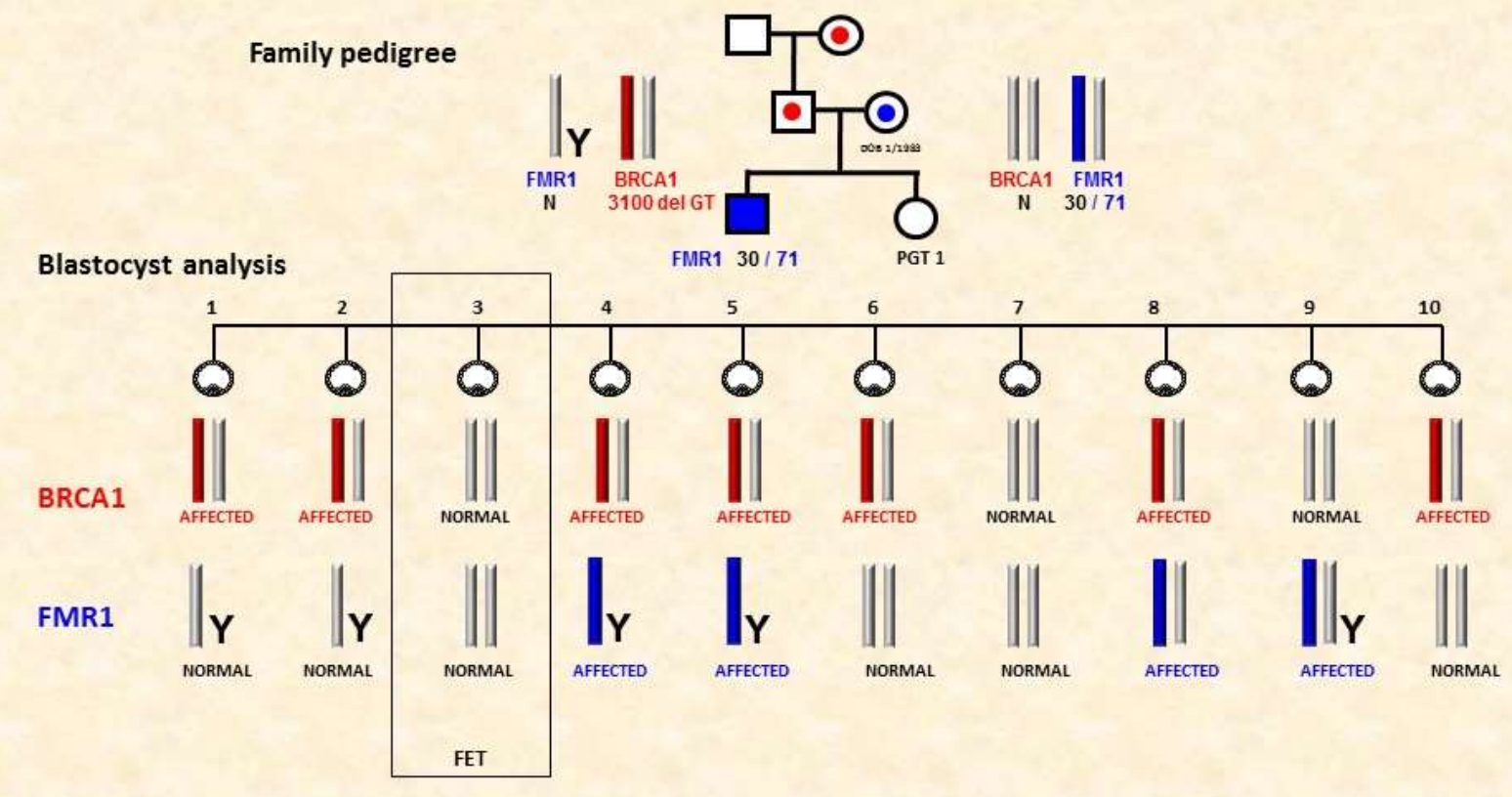

Figure 2 Combined PGT-M for paternal mutation BRCA1 gene 3100 del GT, and maternal Fragile-X expansion (FMR1 gene). (see description in the text below).

Figure 2 presents the case of combined PGT for BRCA1, concomitantly with testing for another frequent condition, fragile-X mental retardation (FMR1). The paternal partner in this case was a carrier of BRCA1 gene (3100 del GT), while maternal partner - carrier of fragile X expansion (FMR1). With dominant mode of inheritance of both of these conditions, there is a $50 \%$ chance for the couple to produce an embryos free of each of these genes, thus with only one in four embryos expected to be free of both genes. In fact, of 10 tested embryos tested, only 3 embryos appeared to be free of the paternal BRCA1 gene (embryo \#3, 7 and 9), of which two of appeared to be also free of fragile $X$ expansion FMR1 gene (embryo \#3 and 7), so actually close to the above expected chances of getting embryo free of both genes. One of these embryos (embryo \#3) was transferred, resulting in unaffected pregnancy and birth of baby girl free of FMR gene expansion and also with no predisposition to breast cancer.

With further wider application of ECS (12), inherited predispositions to breast cancer is becoming the major emerging PGT indication. Overall, cancers account already for $13.3 \%$ of all PGT-M cases in our experience, despite still remaining controversy, because these diseases may present beyond early childhood and may not even be expressed in $100 \%$ of the cases [13-14]. Despite the ethical and legal issues involved in PGT for late-onset disorders with genetic predisposition, such as breast cancer, an increasing number of patients still consider PGT to be their preferable option. Thus, oncologic services may consider informing patients at risk for producing offspring with predisposition to breast cancer that an option exist for them to avoid such risk through PGT.

\section{References}

1. Rechitsky S, Verlinsky O, Chistokhina A, et al. (2002) Preimplantation genetic diagnosis for cancer predisposition. Reprod Biomed Online. 4:148-155.

2. Rechitsky S, Kuliev A. (2010) Novel indications for preimplantation genetic diagnosis. 10th annual international congress on preimplantation genetic disgnosis, 5-8 May 2010, Montpellier, France. Reprod Biomed Online. 20(Suppl):S1-2.

3. Verlinsky Y, Rechitsky S, Verlinsky O, et al. (2001) Preimplantation diagnosis for p53 tumor suppressor gene mutations. Reprod Biomed Online. 2:102-105.

4. Jasper MJ, Liebelt J, Hussey ND. (2007) Preimplantation genetic diagnosis for cancer predisposition syndromes. Prenat Diagn; 27:447-456.

5. Sagi M, Weinberg N, Eilat A, et al. (2008) Preimplantation genetic diagnosis for BRCA1 exon 13 duplication mutation using linked polymorphic markers resulting in a live birth. Prenat Diagn; 28:292- 298.

6. Moutou C, Gardes N, Nicod JC, Viville S. (2009) Preimplantation genetic diagnosis for BRCA1/2 - a novel clinical experience. Eur J Obstet Gynecol Reprod Biol.; 45:9-13.

7. Kuliev A, Rechitsky S, Simpson JL. (2020) Practical Preimplantation Genetic Testing. $3^{\text {rd }}$ Edition. Springer Nature.

8. Kuliev A, Rechitsky S, Verlinsky O. Atlas of Preimplantation Genetic Diagnosis. An Illustrated Textbook. Third Edition. Taylor \& Francis. London, 2014 
9. Preimplantation Genetic Diagnosis International Society (PGDIS). Guidelines for good practice in PGD: program requirements and laboratory quality assurance. Reprod BioMed Online 2008; 16:134-147

10. ESHRE (2020) PGT Consortium good practice recommendations for the organization of PGT Human Reproduction Open, Volume 2020, Issue 3, doi.org/10.1093/hropen/hoaa021.

11. Rechitsky S, Pakhalchuk T, Goodman A, San-Ramos J, Zlatopolsky Z, Kuliev A. (2015) First systematic experience of combined PGD for single gene disorders and/or Preimplantation HLA typing with 24-chromosome aneuploidy testing, Fertility \& Sterility, 103(2): 503-512
12. Simpson JL, Rechitsky S, Kuliev A. (2019) Before the beginning: the genetic risk of a couple aiming to conceive. Fertil Steril; 112:622-630

13. Vadaparampil ST, Quinn GP, Knapp C, Malo TL, Friedman S. (2009) Factors associated with preimplantation genetic diagnosis acceptance among women concerned about hereditary breast and ovarian cancer. Genet Med.; 11:757-765.

14. Quinn GP, Vadaparampil ST, King LM, Miree CA, Friedman S. (2009) Conflict between values and technology: perceptions of preimplantation genetic diagnosis among women at increased risk for hereditary breast and ovarian cancer. Fam Cancer. 8:441- 449 . (cc) (f)

This work is licensed under Creative

Commons Attribution 4.0 License

To Submit Your Article Click Here:

Submit Manuscript

DOI: $10.31579 / 2641-5194 / 101$

Ready to submit your research? Choose Auctores and benefit from:

$>$ fast, convenient online submission

$>$ rigorous peer review by experienced research in your field

$>$ rapid publication on acceptance

$>$ authors retain copyrights

$>$ unique DOI for all articles

$>$ immediate, unrestricted online access

At Auctores, research is always in progress.

Learn more https://auctoresonline.org/journals/gastroenterologypancreatology-and-hepatobilary-disorders- 